index of at least 8 million articles from 17,000 journals and magazines. It also has arrangements with more than 35 libraries to retrieve documents from their archives.

But the suing authors express little sympathy for Shaw's position. "If they can't figure out how to distribute material legally, they should get into another line of work," says Ryan. "People did research before the Internet. Rights and responsibilities need to keep up with technology."

Alexander Fowler, of the Electronic Frontier Foundation of San Francisco, agrees that rights of authors and Internet technology can collide. "It is unfortunate that we are still locked into a paper-based distribution model," says Fowler. "We have to buy reprints to disseminate ideas; we potentially infringe copyrights if we put our own articles on our own websites."

Working with the American Academy of Arts and Sciences, Fowler and Bachrach are among a dozen authors who recently published a paper in Science advocating that scientists should retain the rights to their articles after they are first published. This runs counter to the view of some journals, such as Science and Nature, whose publishers seek to retain copyright, arguing that value has been added by the selection and editing process.

The creators of The UnCover Co. clearly had a vision when the company was started five years ago in Denver by a group of academic librarians. Nearly 20 years ago, the librarians, headed by Shaw, created the Colorado Alliance of Research Libraries (CARL), a nonprofit organization designed to assist academic libraries in the state with inter-library transfers of publications.

As the computerized information age bloomed, the group was well positioned to expand and profit from new technologies. A decade ago, Shaw and colleagues left the nonprofit alliance and started the for-profit CARL Corporation, which then gave birth to The UnCover Co. Shaw and the other founders have since sold their stakes in CARL to a corporation.

Attorneys for The UnCover Co. are seeking to appeal against the judge's decision. The full ramifications of the ruling will not be known for some time, but it could set a major precedent in copyright law.

The lawsuit against The UnCover Co. is a class action, where the five suing authors are acting on behalf of any other authors whose copyrights may have been infringed. It seeks to recover damages for any authors who had their work distributed without permission during the three years before the filing of the lawsuit in October 1997.

At a hearing next week, attorneys for the authors will seek court approval for a fuller description of the class of authors to be included in the lawsuit. Both sides will then proceed with preparations for a future trial to determine damages.

Rex Dalton

\title{
UK initiatives aim to boost high-tech investment
}

[LONDON] The British government has announced a series of measures to help universities overcome the barriers to commercializing the results of their scientific research. The most concrete is a $£ 25$ million (US\$41 million) grant to create between six and eight 'Institutes of Enterprise' attached to universities.

The measures are the latest - and perhaps the most concerted - attempts to address the widely-held concern that Britain lags behind its competitors in turning high quality research into commercial success. The new institutes, for example, will teach entrepreneurship and business skills, and provide university start-up companies with expert financial analysis.

The measures were announced last week by Britain's Chancellor of the Exchequer Gordon Brown in a report outlining the thinking behind the forthcoming budget.

Brown announced that the government is considering offering a tax credit for small and medium sized companies yet to make a profit. The size of the credit will depend on the volume of research and development expenditure, and is designed to stop these companies cutting back on R\&D spending as they struggle to pay taxes.

The government will also announce in the budget whether it will give tax incentives on share ownership to key managers of small high technology companies. This would allow technology start-up companies to attract and retain top managers.

Both moves were recommended by a government-appointed committee of representatives of high technology companies and the investment community, which looked at ways of improving the financing of high technology businesses. The committee, chaired by Sir Peter Williams, chairman of the scientific instrumentation company Oxford Instruments, published its report last week.

The Williams committee is among the many groups - including universities, trades unions, and the pressure group Save British Science - to have welcomed the government's measures. But Williams himself says more needs to be done if the government is serious about gaining greater economic benefit from research.

The committee found that a key difficulty is the British reluctance to invest in new high technology companies at the start-up stage. Last year, total UK high technology venture capital amounted to $\mathfrak{3} 49$ million, compared

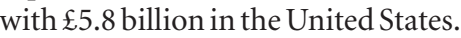

Only 5 per cent of British venture capital goes to start up companies, which is less than in the United States. Similarly, in the United States, 5 per cent of pension fund assets are invested in venture capital. But in the United Kingdom, pension funds, the largest investors in the Stock Exchange, contribute just 0.75 per cent. More than half of the venture capital invested in British companies comes from overseas.

Investment decisions - including those for long-term finance such as pension funds - are often based on short term performance statistics. One reason for the lack of high technology venture capital from British insurance companies and pension funds, says Williams, is an outdated perception that early stage technology venture capital is too risky in the short term.

The Williams report quotes data from the British Venture Capital Association showing that early stage companies have been providing an average 22.9 per cent

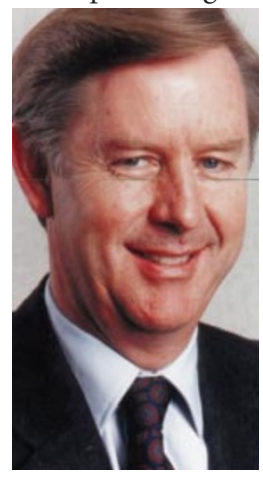
annual return on investment for the past three years, comparable to the performance of the top 100 companies listed on the London Stock Exchange.

More money might flow into early-stage technology companies, the committee believes, if the government sets up special investment Williams: keen to see trusts exempt from more taxincentives. capital gains tax that consist only of new high technology companies. Big investment institutions and individuals should be allowed to invest.

The relatively large tax burden on investors also limits investment in new technology companies, says Williams. His committee believes that a lowering of capital gains tax would lead to a rise in venture capital investment, as it did in the United States when taxes were lowered in 1982.

The committee wants the government to exempt from capital gains tax investors who have held stocks in newly-established high technology companies for five years. But Treasury officials say this is unlikely to be in the next budget, as the government relaxed capital gains tax only last year.

The Williams committee also highlighted communication difficulties between technology companies and investors as a barrier to the commercialization of research. Investors should understand that the results of life science research can take up to 15 years to reach the market.

NATURE |VOL 396 | 12 NOVEMBER1998 | www.nature.com 